\title{
Field evaluation of weather-based spray programs for the control of downy mildew of lettuce (Lactuca sativa), caused by Bremia lactucae, in Quebec and Ontario
}

\author{
M.H.Y. Hovius., O. Carisse, V. Philion, and M.R. McDonald
}

\begin{abstract}
Each year, downy mildew caused by Bremia lactucae occurs in lettuce-producing regions of Quebec and Ontario. Trials were conducted to determine if the disease could be managed with fewer fungicide applications, using disease forecasting. Disease-forecasting programs designed to time the application of fungicide sprays were evaluated for control of downy mildew of lettuce in 1997 and 1998 at 9 field sites. Disease forecasting was based on lesion development following a recorded sporulation-infection period (SIP), with leaf wetness between 3:00 AM and 10:00 AM and temperature between 5 and $20{ }^{\circ} \mathrm{C}$. Presymptom sprays with the protectant fungicide mancozeb were applied before lesions were expected; they were based on 110 accumulated degree-days following a SIP, but not within 7 days of a previous spray. Post-latent-period sprays with the systemic fungicide metalaxyl-M in combination with mancozeb were applied after forecasted lesion development; they were based on 135 accumulated degree-days, but not within 14 days of a previous spray. The effects of forecasted sprays were compared with those of weekly applications of mancozeb and with those of metalaxyl-M or metalaxyl applied in furrow at the time of seeding or transplanting. Downy mildew developed at 7 of the 9 sites. The number of SIPs recorded at all sites ranged from 7 to 17. In 8 of the 9 sites, there were fewer mancozeb applications with the presymptom program than with the weekly sprays, that is a reduction of one, two, and three sprays at six, one, and one sites, respectively. This resulted in a 16\%-60\% reduction in applied fungicide. When metalaxyl-M plus mancozeb was applied according to the post-latent-period forecast, one or two sprays were required, that is a reduction of two, three, and four applications at four, three, and two sites, respectively, compared with the weekly application of mancozeb alone. Metalaxyl-M or metalaxyl applied in furrow provided control for 30-40 days after seeding or transplanting. The number of fungicide applications can be reduced with acceptable disease control if a forecasting program is followed.
\end{abstract}

Key words: disease forecasting, disease management, metalaxyl-M, lettuce, downy mildew, Bremia lactucae.

Résumé : À chaque année, le mildiou causé par le Bremia lactucae affecte la laitue dans les régions productrices du Québec et de l'Ontario. Des essais furent effectués pour déterminer si la maladie pouvait être combattue avec moins d'applications de fongicide en faisant appel à un modèle de prévision de la maladie. En 1997 et 1998, des modèles de prévision conçus pour choisir le moment des traitements fongicides contre le mildiou de la laitue furent évalués sur le terrain à 9 sites. La prévision était basée sur le développement de lésions suivant une période enregistrée de mouillure des feuilles propice à la sporulation et l'infection, située entre 3:00 $\mathrm{AM}$ et 10:00 $\mathrm{AM}$ et à une température entre 5 et $20{ }^{\circ} \mathrm{C}$. Des pulvérisations présymptomatiques de mancozèbe, un fongicide à action préventive, furent effectuées avant l'apparition attendue des lésions; elles furent établies en fonction de 110 degrés jours accumulés après une période propice à la sporulation et l'infection, mais pas à l'intérieur des 7 jours qui suivaient une application précédente. Des pulvérisations après la période de latence avec le fongicide systémique métalaxyl-M en combinaison avec du mancozèbe furent effectuées après le développement prévu des lésions; elles furent établies en fonction de 135 degrés-jours accumulés, mais pas à l'intérieur des 14 jours qui suivaient une application précédente. Les effets des applications prévues furent comparés à ceux des applications hebdomadaires de mancozèbe et à ceux du métalaxyl-M ou du métalaxyl appliqué

Accepted 21 December 2006.

M.H.Y. Hovius and M.R. McDonald. ${ }^{\mathbf{1}}$ Department of Plant Agriculture, University of Guelph, Guelph, ON N1G 2W1, Canada. O. Carisse. Horticultural Research and Development Centre, Agriculture and Agri-Food Canada, 430 Gouin Boulevard, St-Jean-sur-Richelieu, QC J3B 3E6, Canada.

V. Philion. Institut de recherche et de développement en agroenvironnement, St-Hyacinthe, QC J2S 7B8, Canada.

${ }^{1}$ Corresponding author (e-mail: mrmcdona@uoguelph.ca). 
dans le sillon au semis ou à la transplantation. Le mildiou s'est développé à 7 des 9 sites. Le nombre de périodes propices à la sporulation et l'infection enregistrées à tous les sites varia de 7 à 17. Dans 8 des 9 sites, il y a eu moins d'applications de mancozèbe avec le programme présymptomatique qu'avec les applications hebdomadaires, soit une réduction de une, deux et trois applications à respectivement six, un et un sites. Il en résulta une diminution de $16 \%$ à $60 \%$ de fongicide appliqué. Lorsque la combinaison métalaxyl-M plus mancozèbe fut appliquée selon la prévision après la période de latence, une ou deux applications furent nécessaires, soit une réduction de deux, trois et quatre applications à respectivement quatre, trois et deux sites, comparativement à des applications hebdomadaires de mancozèbe seul. Le métalaxyl-M ou le métalaxyl appliqué dans le sillon maîtrisèrent la maladie durant 30 à 40 jours après le semis ou la transplantation. Tout en donnant un degré de lutte suffisant, le nombre d'applications de fongicides peut être réduit si un modèle de prévision de la maladie est appliqué.

Mots-clés : modèle de prévision, lutte antiparasitaire, métalaxyl-M, laitue, mildiou, Bremia lactucae.

\section{Introduction}

Downy mildew of lettuce (Lactuca sativa L.), caused by Bremia lactucae Regel, is an important disease that occurs during cool and wet weather (Crute 1979; Wicks et al. 1993). Bremia lactucae attacks plants in the genus Lactuca at any growth stage (Dickinson and Crute 1974; Carisse and Philion 2002). Symptoms appear first on the under side of the leaf and, in most cases, larger veins limit lesion size (Crute and Dixon 1981). Sporulation occurs under conditions of high humidity on infected tissues producing a downy mat of white sporangiophores. The pathogen rarely kills the plants, but because lettuce is mainly grown for the fresh market, any blemishes or yellowing of the leaves makes the crop unmarketable and may promote rot during postharvest transit and storage (Scherm and van Bruggen 1994a; Carisse and Philion 2002).

Breeding programs aimed at finding disease-resistant cultivars are challenged by a rapid development of new races of the pathogen (Crute and Johnson 1976; Michelmore et al. 1984; Farrara et al. 1987; Ilott et al. 1989; Schettini et al. 1991). Growers often rely on weekly applications of protectant (ethylene bisdithiocarbamate) fungicides for disease control (Raid and Datnoff 1990; Wu et al. 2002) because of the prevalence of populations of Bremia lactucae resistant to metalaxyl-M and fosetyl-aluminium fungicides and because of the high value of the crop. This strategy is expensive and not always effective for control of downy mildew (Raid and Datnoff 1990). These considerations have prompted a need for alternative control strategies, including a more efficient use of available fungicides through optimal timing of applications based on weather and crop-environment conditions conducive to disease development (Scherm and van Bruggen 1994a, 1994b). Timing of fungicide applications based on the microclimate and pathogen biology have the potential to improve disease control with fewer fungicide applications.

Metalaxyl-M is registered in Canada and the United States as Ridomil Gold ${ }^{\circledR} 1 \mathrm{G}$ (metalaxyl-M 1\%; Syngenta Crop Protection Canada Inc., Guelph, Ont.) for in-furrow treatment in control of pythium damping-off and stunt diseases on direct-seeded lettuce but not on lettuce grown from transplants. This product has also proven to be effective for control of downy mildew but is not registered for this use on transplanted or seeded lettuce (Yuen and Lorbeer 1983). If metalaxyl-M is applied in furrow for lettuce, possible effects on downy mildew should be taken into consideration.

Sporangia of Bremia lactucae are produced at night when temperatures are cool $\left(5-20{ }^{\circ} \mathrm{C}\right)$ and leaf tissue is wet (Fletcher 1976); they are liberated during the day (Crute and Dixon 1981; Scherm and van Bruggen 1993, 1995) and can infect lettuce at any time during growth (Dickinson and Crute 1974; Carisse and Philion 2002). A high percentage of sporangia survive only a few hours, depending on solarradiation levels. Therefore, most infection occurs within a couple of hours after liberation of sporangia ( $\mathrm{Su}$ et al. 1998; $\mathrm{Wu}$ et al. 2000). Furthermore, the sporangia can infect only lettuce leaves that are bearing free water (Crute and Dixon 1981). Consequently, sporulation and infection are often concomitant, occurring during the morning (Scherm and van Bruggen 1994a, 1995). The most important factor for successful infection is the duration of morning leaf wetness, which must last for a minimum of $4 \mathrm{~h}$ at temperatures between 5 and $25{ }^{\circ} \mathrm{C}$ (Scherm and van Bruggen 1994a). Such conditions were considered a sporulation-infection period (SIP) if night-time temperatures preceding the leafwetness period were between 5 and $20^{\circ} \mathrm{C}$.

The latent period does not vary much under fluctuating temperatures such as those found in the field, unlike sporulation and infection (Scherm and van Bruggen 1994b). For practical purposes, the first symptoms appear 8-9 days after the initiation of infection or at 115-125 degree-days (DD) on a base of $0{ }^{\circ} \mathrm{C}$ (Scherm and van Bruggen 1994b). If we consider that the sporulation potential of a given lesion will be exhausted within a few hours, it would be possible to time fungicide applications just prior to sporulation to protect lettuce heads from infection. Similarly, given favourable conditions for concomitant sporulation and infection, it should be possible to time eradicative fungicide applications just after SIPs to inhibit fungal growth in host tissues (Nene and Thapliyal 1993).

Systems to forescast downy mildew on lettuce have been developed (Scherm and van Bruggen 1994a; Kushalappa 2001; Wu et al. 2002). The system proposed by Kushlappa (2001), called BREMCAST, is based on the definition of a sporulation-infection period as a continuous leaf wetness for 3-5 h before dawn, continuing until 10 AM. Once a SIP is recorded, a fungicide should be applied. After the effective period of the fungicide has passed, monitoring for SIPs starts again. This system accurately predicted SIPs and 
Table 1. The number of sporulation-infection periods (SIPs) and the number of fungicide applications for the control of downy mildew [Bremia lactucae] on crisphead lettuce, Lactuca sativa 'Ithaca', grown in muck soil in Quebec and Ontario in 1997-1998.

\begin{tabular}{|c|c|c|c|c|c|c|c|c|}
\hline \multirow[b]{2}{*}{$\begin{array}{l}\text { Field } \\
\text { site }\end{array}$} & \multirow[b]{2}{*}{ Location $^{a}$} & \multicolumn{3}{|c|}{$\underline{\text { Plant establishment }}$} & \multirow[b]{2}{*}{$\begin{array}{l}\text { No. of } \\
\text { SIPs }^{b}\end{array}$} & \multicolumn{3}{|c|}{ No. of fungicide applications } \\
\hline & & Year & Date & Type & & $\begin{array}{l}\text { Presymptom } \\
\text { forecasting } \\
\text { treatment }^{c}\end{array}$ & $\begin{array}{l}\text { Post-latent-period } \\
\text { forecasting } \\
\text { treatment }^{d}\end{array}$ & $\begin{array}{l}\text { Conventional } \\
\text { spray } \\
\text { treatment }^{e}\end{array}$ \\
\hline 1 & Quebec RS & 1997 & 31 July & Transplant & 15 & 5 & 2 & 6 \\
\hline 2 & Quebec RS & 1998 & 11 August & Transplant & 15 & 5 & 2 & 5 \\
\hline 3 & Ontario RS & 1997 & 26 May & Seeded & 17 & 3 & 2 & 4 \\
\hline 6 & Ontario RS & 1998 & 7 May & Transplant & 7 & 4 & 2 & 5 \\
\hline 7 & Ontario RS & 1998 & 25 May & Seeded & 11 & 2 & 1 & 4 \\
\hline 8 & Ontario RS & 1998 & 28 July & Seeded & 16 & 3 & 2 & 4 \\
\hline 9 & Ontario $\mathrm{CF}$ & 1998 & 10 July & Seeded & 12 & 2 & 1 & 5 \\
\hline
\end{tabular}

${ }^{a} \mathrm{RS}$, research-station field plot; CF, commercial field plot.

${ }^{b}$ A SIP consists of continuous leaf wetness from 3:00 AM to 10:00 AM, with temperatures of 5-20 ${ }^{\circ} \mathrm{C}$.

${ }^{c}$ Mancozeb was applied at a rate of $1687.5 \mathrm{~g}$ a.i./ha when 110 degree-days (on a basis of $0{ }^{\circ} \mathrm{C}$ ) had accumulated after a SIP as defined above, but not within 7 days of a previous spray.

${ }^{d}$ Metalaxyl-M at $100 \mathrm{~g}$ a.i./ha plus mancozeb at $1600 \mathrm{~g}$ a.i./ha were applied when 135 degree-days (on a basis of $0{ }^{\circ} \mathrm{C}$ ) had accumulated after a SIP as defined above, but not within 14 days of a previous spray.

${ }^{e}$ Mancozeb was applied at a rate of $1687.5 \mathrm{~g}$ a.i./ha every 7 to 10 days.

subsequent infection approximately $84 \%$ of the time (Kushlappa 2001). In California, field trials testing the forecasting program, based primarily on morning leaf wetness $\geq 3 \mathrm{~h}$ with favourable temperatures (optimum $15^{\circ} \mathrm{C}$ ), demonstrated that the number of fungicide sprays could be reduced by one to three compared with the conventional calendar-based applications, while maintaining disease control (Scherm et al. 1995; Wu et al. 2001a, 2001b). This reduction in fungicide use was similar to that found by Kushalappa (2001).

Forecasting systems could be implemented in most Canadian lettuce-producing areas provided that data on morning leaf wetness were available. However, environmental and growing conditions differ greatly between the southern regions of Quebec and Ontario, where most of Canada's lettuce production occurs, and the Salinas Valley, where much of California's lettuce production is situated. Therefore, before implementing disease forecasting in Canada, the usefulness of forecasting systems for downy mildew on lettuce had to be evaluated in Canadian lettuce-producing regions.

The forecasting model proposed by Scherm and van Bruggen (1995) for downy mildew on lettuce was modified by Philion et al. (1998) to include degree-day calculations post SIP on crisphead lettuce. The present research was conducted to evaluate the modified forecasting system to improve the timing of fungicide application while maintaining or improving disease control. The main objective was to evaluate the forecasting model based on presymptom sprays of mancozeb (Dithane ${ }^{\circledR}$ DG: mancozeb $75 \%$, manganese $15 \%$, zinc equivalent 2\%; Rohm and Haas, Philadelphia, Penn.) or post-latent-periods sprays of metalaxyl-M plus mancozeb (Ridomil Gold MZ: metalaxyl-M 4\%, mancozeb 64\%; Novartis Crop Protection Canada Inc., currently Syngenta Crop Protection Canada Inc.), to maintain or improve disease control with fewer fungicide sprays. The second objective was to determine the efficacy of an in-furrow treatment with metalaxyl-M at seeding or metalaxyl (Ridomil ${ }^{\circledR}$ 2G: metalaxyl 2\%; Novartis Crop Protection Canada Inc., currently Syngenta Crop Protection Canada Inc.) at transplanting, for control of downy mildew, since in-furrow application of metalaxyl-M is registered in Canada for the control of diseases caused by Pythium spp. on direct-seeded lettuce (www. syngenta.ca/pdf/labels/RIDOMIL_Gold_1G_26612_en_bag_label. pdf).

\section{Materials and methods}

\section{Field plot location and establishment}

Plots of crisphead lettuce, L. sativa 'Ithaca', were established in muck soil $(\mathrm{pH}>6.4$, organic matter $>60 \%)$ at the Agriculture and Agri-Food Canada experimental farm in St-Clothilde, Quebec (latitude, $45^{\circ} 10^{\prime} \mathrm{N}$; longitude, $73^{\circ} 40^{\prime} \mathrm{W}$ ), and at the Muck Crops Research Station and in a commercial lettuce field, both located in the Holland Marsh, Ontario (latitude, $44^{\circ} 15^{\prime} \mathrm{N}$; longitude, $75^{\circ} 35^{\prime} \mathrm{W}$ ). Nine field sites were established, 2 in Quebec and 7 in Ontario, over 1997 and 1998. Planting dates, planting type (seeded or transplanted), and location are summarized in Table 1.

Lettuces were either transplanted $30 \mathrm{~cm}$ apart in the rows, with $40 \mathrm{~cm}$ between rows, or seeded and thinned to $30 \mathrm{~cm}$ apart in the rows 14-21 days after seeding, according to commercial practices. The individual plots measured $10 \mathrm{~m} \times$ $2 \mathrm{~m}$ (160 plants per replicate plot) in Quebec and $3.4 \mathrm{~m} \times$ $5 \mathrm{~m}$ (136 plants per replicate plot) in Ontario. All treatments were organized in a randomized complete block design with four blocks.

\section{Measurement of environmental variables}

Leaf wetness and air temperature were assessed every minute by means of an electrical-impedance leaf-wetness sensor (model 237) and a temperature and relative humidity probe (HMP35C), connected to a data logger (CR10X or CR21X), all from Campbell Scientific, Edmonton, Alberta, 
Table 2. Fungicide treatments for control of downy mildew [Bremia lactucae] on crisphead lettuce, Lactuca sativa 'Ithaca', grown in muck soil in Quebec and Ontario in 1997 and 1998.

\begin{tabular}{llll}
\hline & & \multicolumn{2}{l}{ Fungicide application } \\
\cline { 3 - 4 } Treatment & Fungicide (common name) & Rate $(\mathrm{g}$ a.i./ha) & Timing \\
\hline Conventional & Mancozeb & 1687.5 & Every 7-10 days \\
Presymptom forecasting & Mancozeb & 1687.5 & 110 DD after a SIP \\
Post-latent-period forecasting & Metalaxyl-M + mancozeb & $100.0+1600.0$ & 135 DD after a SIP \\
In furrow & Metalaxyl-M & 287.5 & At seeding \\
In furrow & Metalaxyl & 500.0 & At transplanting \\
Control & None & & \\
\hline
\end{tabular}

Note: DD, degree-day on a base of $0{ }^{\circ} \mathrm{C}$, calculated as the daily maximum temperature plus daily minimum temperature divided by two, starting at 6:00 AM on the morning of the day a SIP was recorded; SIP, a sporulation-infection period consisting of continuous leaf wetness from 3:00 AM to 10:00 AM, with temperatures of $5-20^{\circ} \mathrm{C}$.

and stored as 15 min averages. One of each sensor per trial plot was placed within the canopy, at leaf height.

\section{Treatments}

A total of four fungicide treatments and an untreated control were compared (Table 2). A conventional spray treatment with mancozeb at $1687.5 \mathrm{~g}$ of active ingredients (a.i.)/ha was applied every 7-10 days, regardless of weather conditions. In-furrow granular treatments with metalaxyl-M at $287.5 \mathrm{~g}$ a.i./ha at seeding or with metalaxyl at $500 \mathrm{~g}$ a.i./ha at transplanting did not receive any additional fungicide sprays. The untreated control was not included at sites 5 or 9 , the commercial sites, to avoid infecting the grower's lettuce crop.

The two forecasting treatments assessed were: a presymptom treatment with the protectant fungicide mancozeb at the same rate as the conventional spray treatment, and a post-latent-period treatment with the systemic fungicide metalaxyl-M at $100 \mathrm{~g}$ a.i./ha, tank mixed with mancozeb at $1600 \mathrm{~g}$ a.i./ha. The minimum SIP criteria were morning leaf wetness starting no later than at 3:00 AM and ending no earlier than at 10:00 at AM, with an verage temperature between 5 and $20{ }^{\circ} \mathrm{C}$. Once these conditions for a SIP were recorded, degree-days on a base of $0{ }^{\circ} \mathrm{C}$ (calculated as the daily maximum temperature plus daily minimum temperature divided by two) were accumulated starting at 6:00 AM on the morning of the day the SIP was recorded, until the minimum latency requirements were met (115 DD or 8 days, whichever was the longest), and then accumulated further until 135 DD. In the presymptom forecasting treatment, a single application of mancozeb was sprayed just prior to expected symptom development (110 DD). Weather conditions during the latent period (8-11 days) were considered not important. No further fungicide applications were made unless another SIP occurred, in which case degree-days recording began again and mancozeb was applied prior to expected symptom development. Mancozeb was considered effective for a period of 7 days after application. In the post-latent-period forecasting treatment, metalaxyl-M plus mancozeb was applied immediately after $135 \mathrm{DD}$, at the time of expected sporulation. An application of metalaxyl-M was considered effective for 14 days. Recommended control procedures for weeds and insects (Ontario Ministry of Agriculture and Food (OMAF), now OMAFRA (Ontario Ministry of Agriculture, Food and Rural Affairs) 1997) were followed.

\section{Fungicide application}

Foliar fungicide treatments were applied in water at $1000 \mathrm{~L} / \mathrm{ha}$, using a gasoline-powered backpack portable sprayer (model 422, Solo, Sindelfingen, Germany) and a hand-held gun mounted with a single nozzle and a 801 flat spray tip operated at $621 \mathrm{kPa}$ with a flow rate of approximately $2.2 \mathrm{~L} / \mathrm{min}$ at the Quebec sites (1 and 2). Granular metalaxyl was applied in a $5 \mathrm{~cm}$ band below the seedlings as they were transplanted. At the Ontario sites (3-9), foliar fungicide treatments were applied in water at $500 \mathrm{~L} / \mathrm{ha}$ with a tractor-drawn sprayer equipped with Dg Tee jet 8002 VS flat-fan nozzles, operated at $690 \mathrm{kPa}$ (boom), except at the commercial field plots (sites 5 an 9), where the fungicide treatments were applied at $414 \mathrm{kPa}$ with a backpack, handoperated sprayer equipped with a fan-jet nozzle. Granular metalaxyl-M was applied in a $5 \mathrm{~cm}$ wide band with the seed at the time of seeding.

\section{Disease evaluation}

The number of lesions per plant was assessed on 20 plants per replicate plot, twice a week, at sites 1 and 2 (in Quebec). At the remainder of the sites (in Ontario), disease incidence was recorded on 15 plants per replicate plot daily. For each treatment, the area under the disease progress curve (AUDPC) between each sampling date was calculated by the midpoint rule, averaging the number of lesions (Quebec) or disease incidence (Ontario) of two consecutive assessment dates. Total AUDPC was determined by summation for all periods.

Disease severity was recorded at harvest. At sites 1 and 2, 20 heads per plot were sampled and total numbers of lesions per head were recorded. At sites 3, 4, 6, 7, and 8, 25 heads per plot were sampled and disease severity was assessed using a scale of 0-5. Lettuce heads were assigned to one of the six rating classes on the basis of the number of lesions, as follows: 0, no lesions; 1, 1 lesion; 2, 2-5 lesions; 3, 6-10 lesions; 4, 11-15 lesions; and 5, over 15 lesions. The disease severity (DS) ratings were converted to a 0-100 scale, using the formula of Kobriger and Hagedorn (1983):

$$
\mathrm{DS}=\frac{\sum R N_{R}}{N_{\mathrm{T}}(n-1)} \times 100
$$

where $R$ is the rating-class number, varying from 0 to $5 ; N_{R}$ is the number of heads in the rating class $R ; N_{\mathrm{T}}$ is the total number of heads per sample; and $n$ is the number of rating classes. 
Table 3. Area under the disease progress curve of downy mildew [Bremia lactucae] on crisphead lettuce, Lactuca sativa 'Ithaca', grown in muck soil in Quebec and Ontario in 1997 and 1998.

\begin{tabular}{|c|c|c|c|c|c|c|}
\hline \multirow[b]{3}{*}{ Treatment } & \multicolumn{6}{|c|}{ Area under the disease progress curve } \\
\hline & \multicolumn{2}{|l|}{ Quebec } & \multicolumn{4}{|l|}{ Ontario } \\
\hline & 1997 (site 1) & 1998 (site 2) & 1997 (site 3) & 1997 (site 4) & 1998 (site 8) & 1998 (site 9) \\
\hline Conventional $^{a}$ & $326.0 \mathrm{ab}$ & $456.9 \mathrm{~b}$ & $3.3 \mathrm{c}$ & $1199.5 \mathrm{ab}$ & $279.5 \mathrm{~b}$ & $165.8 \mathrm{~d}$ \\
\hline Presymptom forecasting $^{b}$ & $186.8 \mathrm{~b}$ & $471.9 \mathrm{~b}$ & $5.8 \mathrm{c}$ & $477.0 \mathrm{~b}$ & 599.8 a & $930.0 \mathrm{~b}$ \\
\hline Post-latent-period forecasting ${ }^{c}$ & $159.7 \mathrm{~b}$ & $259.4 \mathrm{c}$ & $171.7 \mathrm{~b}$ & $1223.7 \mathrm{ab}$ & $182.7 \mathrm{~b}$ & $801.7 \mathrm{c}$ \\
\hline
\end{tabular}

Note: Numbers within a column followed by the same letter were not significantly different at $P=0.05$, according to Fisher's protected least significant difference (LSD).

${ }^{a}$ Mancozeb was applied at a rate of $1687.5 \mathrm{~g}$ a.i./ha every 7 to 10 days.

${ }^{b}$ Mancozeb was applied at a rate of $1687.5 \mathrm{~g}$ a.i./ha when 110 degree-days (on a basis of $0{ }^{\circ} \mathrm{C}$ ) had accumulated after a sporulation-infection period (SIP, a continuous leaf wetness from 3:00 AM to 10:00 AM, with temperatures of 5-20 ${ }^{\circ} \mathrm{C}$ ), but not within 7 days of a previous spray.

${ }^{c}$ Metalaxyl-M at $100 \mathrm{~g}$ a.i./ha plus mancozeb at $1600 \mathrm{~g}$ a.i./ha were applied when 135 degree-days (on a basis of $0{ }^{\circ} \mathrm{C}$ ) had accumulated after a SIP as defined above, but not within 14 days of a previous spray.

${ }^{d}$ Metalaxyl-M (287.5 g a.i./ha) was applied in furrow at seeding, and metalaxyl (500 g a.i./ha), in furrow at transplanting.

After assessment, the lettuce heads were trimmed until only healthy leaves were left on the head and were weighed to determine yield. Disease severity and harvest masses were not assessed at sites 5 and 9, the commercial field sites.

\section{Statistical analysis}

All data were checked for normality, using the WilkShapiro test (Shapiro and Francia 1972) and were logarithmically transformed to improve normality if necessary. Analyses of variance were performed to test the effects of treatment on AUDPC, the number of lesions (Quebec), disease severity at harvest (Ontario), and yield. Significant differences among treatments were detected by Fisher's protected least significant difference (Fisher 1935) according to $P<0.05$. Data were analyzed using the function general analysis of variance and the linear models section of Statistix7, version 7 (Analytical Software, Tallahassee, Fla.) and PROC GLM of SAS, version 8 (SAS Institute Inc. 1999).

\section{Results}

Disease symptoms were first observed 23 and 57 days after transplanting and seeding at sites 1 (Quebec) and 3 (Ontario), respectively, in 1997. They were observed 7 days after seeding at site 4 (Ontario), before the seedlings were thinned. In 1998, disease symptoms were first observed 8 days after transplanting at site 2 (Quebec) and 43, 28, and 28 days after seeding in Ontario at sites 7, 8, and 9, respectively.

The number of SIPs forecasted ranged from 10 to 17 at the different sites in 1997 and from 7 to 16 in 1998 (Table 1). There was a reduction of one mancozeb application in the presymptom forecasting treatment compared with the conventional spray treatment for all the 1997 sites. In 1998, additional reductions of two and three mancozeb sprays were forecasted at sites 7 and 9, respectively, and there was no difference at site 2 in the presymptom forecasting treatment compared with the conventional spray treatment (Table 1). Forecasting based on metalaxyl-M plus mancozeb sprays and post-latent-period treatments resulted in a reduction of two to four sprays per crop in both years.

No disease symptoms were observed in Ontario at site 5, seeded 5 July 1997, and site 6, transplanted 7 May 1998. Later it was discovered that the lettuce at site 5, a commercial field plot, had been treated in furrow with metalaxyl-M. Disease incidence increased at all the other sites over the growing season in 1997 and 1998. Significant differences in AUDPC among the treatments were found at all the sites (Table 3 ) except 7 , where disease severity was low $(<2 \%$, data not shown).

At least two of the fungicide treatments reduced disease in comparison with the untreated control at all sites. However, none of the treatments was consistently the most effective. The presymptom and post-latent-period forecasting treatments each had a lower AUDPC than the untreated control at both of the Quebec sites (sites 1 and 2) and at two of the three sites in Ontario where there was an untreated control (Table 3). The in-furrow metalaxyl-M or metalaxyl treatments were included in five of the six sites where differences among treatments in AUDPC were identified and these were as effective as other fungicide treatments at two of the sites, more effective at one site, and less effective at two sites.

Results of disease assessment at harvest were generally similar to those for AUDPC. Significant differences among treatments were found in numbers of lesions (sites 1 and 2) or disease severity (sites 3, 4, and 5) in harvest assessments (Table 4). Disease severity at harvest was not assessed at site 9, a commercial field. No treatment was consistently most effective, but each of the foliar fungicide treatments reduced disease compared with the untreated control at four of five sites, and the in-furrow fungicide treatment reduced disease at three of four sites.

Differences in yield were found at four of the seven field sites (sites 1, 3, 4, and 6) where mean head masses were recorded (Table 5). Data for the three sites where differences were not found are not shown. There was no disease throughout the season at site 6 and mass per head was lower in the in-furrow treatment than in any of the other treat- 
Table 4. Lesion numbers (in Quebec) and disease severity (in Ontario), at harvest in 1997 and 1998, on crisphead lettuce, Lactuca sativa 'Ithaca', infected with downy mildew [Bremia lactucae].

\begin{tabular}{|c|c|c|c|c|c|}
\hline \multirow[b]{2}{*}{ Treatment } & \multicolumn{2}{|c|}{${\text { Number of lesions, } \text { Quebec }^{e}}^{e}$} & \multicolumn{3}{|c|}{$\underline{\text { Disease severity, Ontario }^{f}}$} \\
\hline & 1997 (site 1) & 1998 (site 2) & 1997 (site 3) & 1997 (site 4) & 1998 (site 8) \\
\hline None & $147.9 \mathrm{a}$ & $45.1 \mathrm{a}$ & $13.0 \mathrm{a}$ & $51.8 \mathrm{a}$ & $57.6 \mathrm{a}$ \\
\hline Presymptom forecasting $^{b}$ & $23.5 \mathrm{c}$ & $34.8 \mathrm{ab}$ & $0.5 \mathrm{~b}$ & $12.5 \mathrm{c}$ & $32.0 \mathrm{bc}$ \\
\hline Post-latent-period forecasting $c$ & $23.6 \mathrm{c}$ & $26.3 \mathrm{~b}$ & $0.3 \mathrm{~b}$ & $45.0 \mathrm{ab}$ & $7.0 \mathrm{~d}$ \\
\hline In furrow ${ }^{d}$ & $55.3 \mathrm{~b}$ & $4.8 \mathrm{c}$ & - & $24.8 \mathrm{bc}$ & $46.4 \mathrm{a}$ \\
\hline
\end{tabular}

Note: Numbers within a column followed by the same letter were not significantly different at $P=0.05$, according to Fisher's protected least significant difference (LSD).

${ }^{a}$ Mancozeb was applied at a rate of $1687.5 \mathrm{~g}$ a.i./ha every 7 to 10 days.

${ }^{b}$ Mancozeb was applied at a rate of $1687.5 \mathrm{~g}$ a.i./ha when 110 degree-days (on a basis of $0{ }^{\circ} \mathrm{C}$ ) had accumulated after a sporulation-infection period (SIP, a continuous leaf wetness from 3:00 AM to 10:00 AM, with temperatures of 5-20 ${ }^{\circ} \mathrm{C}$ ), but not within 7 days of a previous spray.

${ }^{c}$ Metalaxyl-M at $100 \mathrm{~g}$ a.i./ha plus mancozeb at $1600 \mathrm{~g}$ a.i./ha were applied when 135 degree-days (on a basis of $0{ }^{\circ} \mathrm{C}$ ) had accumulated after a SIP as defined above, but not within 14 days of a previous spray.

${ }^{d}$ Metalaxyl-M (287.5 g a.i./ha) was applied in furrow at seeding, and metalaxyl (500 g a.i./ha), in furrow at transplanting.

${ }^{e}$ Mean number of lesions per head caused by B. lactucae on 20 lettuce heads per plot.

${ }^{f}$ Disease severity from 25 lettuce heads per plot, assessed using a scale of $0-5$ per head as follows: 0 , no lesions; 1 , 1 lesion; 2 = 2-5 lesions; 3 , 6-10 lesions; 4, 11-15 lesions; and 5, over 15 lesions,. Severity assessment was converted to a 0-100 scale as follows:

$$
\mathrm{DS}=\frac{\sum R N_{R}}{N_{\mathrm{T}}(n-1)} \times 100
$$

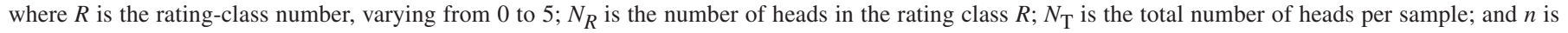
the number of rating classes.

ments. This may indicate some phytotoxicity of the in-furrow metalaxyl-M application in absence of disease.

\section{Discussion}

Downy mildew occurred in both years, in Quebec and Ontario, at different levels of severity, indicating that a forecasting system for downy mildew would be useful for improving fungicide use. Although there were some differences in disease rating methods used at the Quebec and Ontario field sites, the results were similar for both disease management and yield. Differences in AUDPC and disease severity at harvest were found at six of the seven sites where disease developed. It was hypothesized that the forecasting systems would always result in better control than the untreated control. Although the timing of fungicide applications was predicted by the forecasting systems, inclement weather conditions at some times may have resulted in a delay in fungicide application of one to a few days, resulting in less disease control than expected. Differences in yield at harvest were found at four of the seven sites where marketable yield (mass per head) was assessed. Fungicide application resulted in higher yields, compared with the untreated control, at three of the four sites. Therefore, the application of fungicides according to SIPs had no detrimental affect on yield and resulted in yield increases at approximately half of the sites.

SIPs were recorded at all 9 field sites, whether disease was observed or not. The number of mancozeb fungicide applications in the forecasted presymptom treatment was reduced compared with the conventional treatment in 8 of the 9 field sites. Similar reductions of one or two sprays in forecasting systems compared with regular calendar sprays were observed by other researchers (Scherm et al. 1995; Wu et al. 2001b). Only one or two sprays were required by the forecasted post-latent-period treatment with metalaxyl-M plus mancozeb. The reduction in the number of sprays in the forecasting treatments were primarily the result of the delay in the first spray. In most cases, the forecasted presymptom application of mancozeb was delayed by 7-10 days after the first calendar-based spray in Ontario and by more than 10 days at the Quebec field sites.

Research on forecasting models for downy mildew of onion caused by Peronospora destructor (Berk.) Casp. has shown that better results are achieved when fungicides are sprayed to control the first SIP (Jesperson and Sutton 1987). Koike and Henderson (1997) timed the first spray application against downy mildew of lettuce with the first SIP, after initial signs of infection. Future experiments with a forecasting model for downy mildew should include treatments where the first spray is delayed until the inoculum in the field reaches a threshold. Threshold levels for Bremia lactucae still need to be established. In other predictive systems, such as the one developed for the management of botrytis leaf blight of onion caused by Botrytis squamosa J.C. Walker, fungicide sprays were initiated once the disease had reach the critical level of one lesion per leaf (Shoemaker and Lorbeer 1977). A forecasting system based on airborne inoculum might be more effective for downy mildew of lettuce.

A different forecasting strategy using predicted morning leaf wetness was tested by Scherm et al. (1995). Fungicide sprays were made prior to a forecasted infection period and resulted in a reduction of the number of fungicide sprays by up to $67 \%$ as compared with the calendar-based schedule. The level of disease was extremely low in most of these trials, i.e., less than one lesion per plant. In the only trial where disease intensity was higher (approximately 18 lesions per plant), the forecasted sprays failed to adequately control 
Table 5. Yield of crisphead lettuce, Lactuca sativa 'Ithaca', at harvest following treatments with different fungicides, according to different spray programs, for control of downy mildew [Bremia lactucae] in Quebec and Ontario in 1997 and (or) 1998.

\begin{tabular}{|c|c|c|c|c|}
\hline \multirow[b]{3}{*}{ Treatment } & \multicolumn{4}{|c|}{ Lettuce yield (mean mass per head, $\mathrm{g})^{e}$} \\
\hline & \multirow{2}{*}{$\frac{\text { Quebec }}{1997(\text { site } 1)}$} & \multicolumn{3}{|l|}{ Ontario } \\
\hline & & 1997 (site 3) & 1997 (site 4) & 1998 (site 6) \\
\hline None & $76 \mathrm{c}$ & $124 \mathrm{~b}$ & $52 \mathrm{c}$ & $60 \mathrm{a}$ \\
\hline Conventional $^{a}$ & $92 \mathrm{~b}$ & 146 a & $68 \mathrm{ab}$ & $62 \mathrm{a}$ \\
\hline Presymptom forecasting $^{b}$ & $95 \mathrm{ab}$ & 146 a & $68 \mathrm{ab}$ & $57 \mathrm{a}$ \\
\hline Post-latent-period forecasting ${ }^{c}$ & $104 \mathrm{a}$ & $135 \mathrm{ab}$ & $56 \mathrm{bc}$ & $62 \mathrm{a}$ \\
\hline In furrow ${ }^{d}$ & $97 \mathrm{ab}$ & - & $78 \mathrm{a}$ & $50 \mathrm{~b}$ \\
\hline $\operatorname{LSD}(P=0.05)$ & 12 & 12 & 13 & 6 \\
\hline
\end{tabular}

\footnotetext{
Note: Numbers within a column followed by the same letter were not significantly different at $P=0.05$, according to Fisher's protected least significant difference (LSD).

${ }^{a}$ Mancozeb was applied at a rate of $1687.5 \mathrm{~g}$ a.i./ha every 7 to 10 days.

${ }^{b}$ Mancozeb was applied at a rate of $1687.5 \mathrm{~g}$ a.i./ha when 110 degree-days (on a basis of $0{ }^{\circ} \mathrm{C}$ ) had accumulated after a sporulation-infection period (SIP, a continuous leaf wetness from 3:00 AM to 10:00 AM, with temperatures of 5-20 ${ }^{\circ} \mathrm{C}$ ), but not within 7 days of a previous spray.

${ }^{c}$ Metalaxyl-M at $100 \mathrm{~g}$ a.i./ha plus mancozeb at $1600 \mathrm{~g}$ a.i./ha were applied when 135 degree-days (on a basis of $0{ }^{\circ} \mathrm{C}$ ) had accumulated after a SIP as defined above, but not within 14 days of a previous spray.

${ }^{d}$ Metalaxyl-M (287.5 g a.i./ha) was applied in furrow at planting.

${ }^{e}$ Yield was determined on lettuce heads trimmed to market standards.
}

the disease. However, it was possible to reduce disease severity with two sprays compared with three in the calendarbased program. This reduction in fungicide applications is similar to what we found using leaf-wetness data to time sprays following a SIP. Attempting to predict SIPs on the basis of the latent period has the advantage of providing growers advance notice, a critical factor in the acceptance of spray advisory programs (Bailey et al. 1994).

The relationship between duration of morning leaf wetness and infection does not seem to hold in all field trials in California (Koike and Henderson 1997). Spore dispersal was observed to occur in the morning (Scherm and van Bruggen 1994a), with the bulk of spore liberation occurring later than 10:00 AM, peaking around noon (Scherm and van Bruggen 1995). Spore dispersal later in the day was sometimes observed in Quebec (Carisse and Philion 2002). Infection could occur in late afternoon or during the night following spore liberation, provided optimal wet leaf conditions are present. This would confirm daytime leaf wetness as one of the most important variables in determining infection days (Scherm and van Bruggen 1994a). Nongerminated spores would only need to survive through late afternoon, until conditions for infection were encountered, even though the spore survival rate might be quite low. This would account for mildew development despite the lack of morning leaf wetness (Koike and Henderson 1997). Regardless, our results indicate that a forecasting model based on fungicides applied prior to or just after expected symptom development would be successful. These findings suggest that symptom expression and sporulation are adequately predicted with the current definition of SIPs and a 115 DD or 8-day latent period, whichever is longest, regardless of when spores are dispersed.

Research on downy mildew of lettuce has shown that the disease occurs and progresses irregularly, varying in intensity from year to year and from field to field (Scherm and van Bruggen 1994a; Kushalappa 2001). We observed that downy mildew did not always develop despite multiple leaf-wetness events or SIPs. At one field site in 1997 (site 5) and 1998 (site 6), no downy mildew symptoms were observed even though there were 11 and 7 recorded SIPs, respectively. (However, site 5, where no disease developed in 1997, was treated in furrow with metalaxyl-M, which may have suppressed the disease.) The lack of disease development in these trials and after some SIPs in the other trials was usually associated with hot weather (maximum temperature $\geq$ $28^{\circ} \mathrm{C}$ ). Very low inoculum may be responsible for the lack of disease. Forecasting systems for downy mildew on onion based on the DOWNCAST program recognize that daytime temperatures in excess of $25^{\circ} \mathrm{C}$ inhibit sporulation the following day (Hildebrand and Sutton 1982). High temperatures might also inhibit or reduce sporulation of Bremia lactucae, and thus reduce the risk of pathogen spread and subsequent disease development. Indeed, there has been a modification to the warning system based on duration of morning leaf wetness for downy mildew on lettuce in California; the system now incorporates an effect of warmer temperatures following an infection period, to reflect that $22{ }^{\circ} \mathrm{C}$ is the upper limit for postpenetration development of Bremia lactucae (Wu et al. 2002).

Symptom development following a recorded SIP closely matched the 6- to 9-day latent period predicted by Scherm and van Bruggen (1994b). In the 6 of 7 sites where disease was observed, symptoms generally appeared 8-9 days after almost every recorded SIP. This confirms the minimum latent period of $8.7 \pm 0.75$ days.

Disease control was successful when morning leaf-wetness and temperature data were used to determine SIP occurrence and to time fungicide applications. The results from these trials show a reduction in the number of fungicide applications while maintaining a good level of disease control, when sprays are properly timed using SIPs. Forecasting for downy mildew within an integrated pest management program in Canadian lettuce-production systems can be 
expected to reduce the number of fungicide applications most of the time and to maintain or improve disease control.

Yuen and Lorbeer (1983) found that four weekly sprays with metalaxyl-M compared with four with mancozeb were more effective at controlling downy mildew. In our trials, the post-latent-period forecasting system with metalaxyl-M plus mancozeb recommended one or two sprays. Disease control was similar in both presymptom and post-latentperiod forecasting systems, although neither was consistently effective. Disease control might have been better with more sprays of metalaxyl-M plus mancozeb, although management of fungicide resistance in Bremia lactucae must be considered.

Multiple applications of metalaxyl-M could lead to insensitivity to metalaxyl-M developing in local Bremia lactucae populations. Metalaxyl-M was first used in 1983 on California lettuce crops, and by 1987 control of downy mildew failed in a number of fields (Crute 1987). Of the four Bremia lactucae pathotypes tested, two were found to be resistant to the fungicide (Schettini et al. 1991). Similar results were reported from Italy (Cobelli et al. 1998). For this reason, metalaxyl-M sprays to control foliar pathogens should be tank mixed with a protectant fungicide, and the fungicide should generally be sold in a commercial mix with mancozeb or other fungicides (Syngenta Crop Protection Canada Inc. 2006). A maximum of three foliar sprays of metalaxyl-M plus mancozeb are recommended for lettuce production in Ontario (OMAF 2004-2005). We are therefore not recommending metalaxyl-M alone in a forecasting system. Similarly, applying metalaxyl-M after sporulation has occurred, as tested in the post-latent-period treatment, could increase the risk of resistance and is not a recommended practice. The presymptom forecasting system with mancozeb alternated with metalaxyl-M plus mancozeb, or other fungicides, should provide effective disease control with efficient use of fungicides.

An in-furrow application of metalaxyl-M at seeding was observed to provide adequate disease control for approximately 60 days (Yuen and Lorbeer 1983), and the control was equivalent to foliar sprays applied throughout the season. Our results indicate that protection usually lasted about 3040 days, depending on disease pressure, for both seeded and transplanted lettuce. This discrepancy may be related to the later development of disease in the seeded plots of Yuen and Lorbeer (1983). An application of metalaxyl-M in furrow at seeding could be supplemented with a mid-season spray (Yuen and Lorbeer 1983), or a granular in-furrow application of metalaxyl-M could be combined with the forecasting model to time a protectant foliar spray 30-40 days post thinning or post transplant if needed. Such a strategy would result in reduced costs of machinery, labor, and active ingredients for adequate disease control. The use of in-furrow metalaxyl-M or metalaxyl for the control of downy mildew is not recommended, because continuous exposure increases the risk that the pathogen develops resistance to these fungicides. However, if the in-furrow treatment is applied, disease forecasting and using fungicides with different modes of action will reduce the potential for resistance to develop in Bremia lactucae.

Newer fungicides are currently being evaluated for registration to control downy mildew on lettuce in Canada. These include fenamidone, dimethomorph, cymoxanil, zoxamide, azoxystrobin, and famoxadone. There is a risk that Bremia lactucae could develop resistance to any of these fungicides. Relying on reducing the number of fungicide applications with a forecasting system such as the one proposed here and on alternating among available fungicide modes of action can help to reduce the cost of disease management and to slow down the development of resistance to fungicides.

\section{Acknowledgements}

This research was supported by Food Systems 2002 program of the OMAFRA, the Plant Program of the University of Guelph - OMAFRA, and by Agriculture and Agri-Food Canada.

\section{References}

Bailey, J.E., Johnson, G.L., and Toth, S.J., Jr. 1994. Evolution of a weather-based peanut leaf spot spray advisory in North Carolina. Plant Dis. 78: 530-535.

Carisse, O., and Philion, V. 2002. Meteorological factors affecting periodicity and concentration of airborne spores of Bremia lactucae. Can. J. Plant Pathol. 24: 184-193.

Cobelli, L., Collina, M., and Brunelli, A. 1998. Occurrence in Italy and characteristics of lettuce downy mildew (Bremia lactucae) resistant to phenylamide fungicides. Eur. J. Plant Pathol. 104: 449-455.

Crute, I.R. 1979. Lettuce mildew - destroyer of quality. ARC Res. Rev. (UK), 5: 9-12.

Crute, I.R. 1987. The occurrence, characteristics, distribution, genetics, and control of a metalaxyl-m-resistant pathotype of Bremia lactucae. Plant Dis. 71: 763-767.

Crute, I.R., and Dixon, G.R. 1981. Downy mildew diseases caused by the genus Bremia Regel. In The downy mildews. Edited by D.M. Spencer. Academic Press, London, UK. pp. 421459.

Crute, I.R., and Johnson, A.G. 1976. The genetic relationship between races of Bremia lactucae and cultivars of Lactuca sativa. Ann. Appl. Biol. 83: 125-137.

Dickinson, C.H., and Crute, I.R. 1974. The influence of seedling age and development on the infection of lettuce by Bremia lactucae. Ann. Appl. Biol. 76: 49-61.

Farrara, B.F., Ilott, T.W., and Michelmore, R.W. 1987. Genetic analysis of factors for resistance to downy mildew (Bremia lactucae) in species of lettuce (Lactuca sativa and L. serricola). Plant Pathol. (London), 36: 499-514.

Fisher, R.A. 1935. The design of experiments. Oliver and Boyd, Edinburgh, UK.

Fletcher, T. 1976. Bremia lactucae oospores, sporangial dissemination and control. Ann. Appl. Biol. 84: 294-298.

Hildebrand, P.D., and Sutton, J.C. 1982. Weather variables in relation to an epidemic of onion downy mildew. Phytopthology, 72: 219-224.

Ilott, T.W., Hulbert, S.H, and Michelmore, R.W. 1989. Genetic analysis of the gene-for-gene interaction between lettuce (Lactuca sativa) and Bremia lactucae. Phytopathology, 79: 888-897.

Jesperson, G.D., and Sutton, J.C. 1987. Evaluation of a forecaster for downy mildew of onion (Allium cepa L.). Crop Prot. 6: $95-103$. 
Kobriger, K.M, and Hagedorn, D.J. 1983. Determination of bean root rot potential in vegetable production fields of Wisconsin's Central Sands. Plant Dis. 67: 177-178.

Koike, S., and Henderson, D. 1997. Implementation of a downy mildew prediction model. California Iceberg Lettuce Advisory Board Research Program, Davis, Calif., Annual Report.

Kushalappa, A.C. 2001. BREMCAST: development of a system to forecast risk levels of downy mildew on lettuce (Bremia lactucae). Int. J. Pest Manag. 47: 1-5.

Michelmore, R.W., Norwood, J.M., Ingram, D.S., Crute, I.R., and Nicholson, P. 1984. The inheritance of virulence in Bremia lactucae to match resistance factors $3,4,5,6,8,9,10$ and 11 in lettuce (Lactuca sativa). Plant Pathol. (London), 33: 301315 .

Nene, Y.L., and Thapliyal, P.N. (Editors). 1993. Fungicides in plant disease control. International Science Publisher, New York.

Ontario Ministry of Agriculture and Food (OMAF). 1997. Vegetable production recommendations 1997. OMAF, now OMAFRA (Ontario Ministry of Agriculture, Food and Rural Affairs), Publication 363. Queen's Printer for Ontario, Toronto, Ont.

Ontario Ministry of Agriculture and Food (OMAF). 2004 2005. Vegetable production recommendations 2004-2005. OMAF, now OMAFRA (Ontario Ministry of Agriculture, Food and Rural Affairs), Publication 363. Queen's Printer for Ontario, Toronto, Ontario.

Philion, V., Carisse, O., and McDonald, M.R. 1998. Field validation of a forecast model for downy mildew of lettuce caused by Bremia lactucae [online]. In 7th International Congress of Plant Pathology. 9-16 August 1998, Edinburgh, UK. Available from http://www.bspp.org.uk/icpp98/2.2/131.html [Abstr. No. 2.2.131].

Raid, R.N., and Datnoff, L.E. 1990. Loss of the EBDC fungicides: impact on control of downy mildew of lettuce. Plant Dis. 74: 829-831.

SAS Institute Inc. 1999. SAS/STAT user's guide. Version 8. SAS Institute Inc., Cary, N.C.

Scherm, H., and van Bruggen, A.H.C. 1993. Response surface models for germination and infection of Bremia lactucae, the fungus causing downy mildew of lettuce. Ecol. Model. 65: 281-296.

Scherm, H., and van Bruggen, A.H.C. 1994a. Weather variables associated with infection of lettuce by downy mildew (Bremia lactucae) in coastal California. Phytopathology, 84: 860-865.

Scherm, H., and van Bruggen, A.H.C. 1994b. Effects of fluctuating temperatures on the latent period of lettuce downy mildew (Bremia lactucae). Phytopathology, 84: 853-859.
Scherm, H., and van Bruggen, A.H.C. 1995. Concurrent spore release and infection of lettuce by Bremia lactucae during mornings with prolonged leaf wetness. Phytopathology, 85: 552555.

Scherm, H., Koeke, S.T., Laemmien, F.F., and van Bruggen, A.H.C. 1995. Field evaluation of spray advisories against lettuce downy mildew (B. lactucae) based on measured or forecast morning leaf wetness. Plant Dis. 79: 511-516.

Schettini, T.M., Legg, E.J., and Michelmore, R.W. 1991. Insensitivity to metalaxyl-m in California populations of Bremia lactucae and resistance of California lettuce cultivars to downy mildew. Phytopathology, 81: 64-70.

Shapiro, S.S., and Francia, R.S. 1972. An approximate analysis of variance test for normality. J. Am. Stat. Assoc. 67: 215-216

Shoemaker, P.B., and Lorbeer, J.W. 1977. Timing initial fungicide application to control botrytis leaf blight epidemics on onions. Phytopathology, 67: 409-414.

Su, H., van Bruggen, A.H.C., and Subbarao, K.V. 1998. Spore release of Bremia lactucae on lettuce is affected by timing of light initiation and decrease in relative humidity. Phytopathology, 90: 67-71.

Syngenta Crop Protection Canada Inc. 2006. Ridomil ${ }^{\circledR}$ Gold 1G. Approved bag for Ridomyl 1G fungicide 26612 04-03-17 [online]. Syngenta Crop Protection Canada Inc., Guelph, Ont. Available from www.syngenta.ca/pdf/labels/RIDOMIL_Gold_ 1G_26612_en_bag_label.pdf

Wicks, T.J., Hall, B., and Pezzaniti, P. 1993. Fungicidal control of downy mildew (Bremia lactucae) on lettuce. Aust. J. Exp. Agric. 33: 381-384.

Wu, B.M., Subbarao, K.V., and van Bruggen, A.H.C. 2000. Factors affecting the survival of Bremia lactucae sporangia deposited on lettuce leaves. Phytopathology, 90: 827-833.

Wu, B.M., van Bruggen, A.H.C., Subbarao, K.V., and Pennings, G.G.H. 2001a. Validation of weather and leaf wetness forecasts for a lettuce downy mildew warning system. Can. J. Plant Pathol. 23: 371-383.

Wu, B.M., Subbarao, K.V.; van Bruggen, A.H.C., and Koike, S.T. 2001b. Comparison of three fungicide spray advisories for lettuce downy mildew. Plant Dis. 85: 895-900.

Wu, B.M., van Bruggen, A.H.C., Subbarao, K.V., and Scherm, H. 2002. Incorporation of temperature and solar radiation thresholds to modify a lettuce downy mildew warning system. Phytopathology, 92: 631-636.

Yuen, J.E., and Lorbeer, J.W. 1983. Metalaxyl-m controls downy mildew and supplements horizontal resistance to Bremia Lactucae in lettuce grown on organic soil in New York. Plant Dis. 67: 615-618. 